\title{
Transition Status of Land Property Values Based on State Land to Be Justice (Study on The Granting of Compensation of Land Development Projects Pemalang - Batang Toll Road)
}

\begin{abstract}
Anisa Humaida ${ }^{1}$ and Umar Ma'ruf ${ }^{2}$
Abstract. Practice transitional land rights usually involve communities affected by development projects such as those in Pemalang-Batang toll road construction project. The method used in this research is juridical empirical method. This research is descriptive. With the research that is descriptive, it can be analyzed and compiled the data collected, so that it can be concluded that a general nature, as well as giving a clear picture of the role of the Notary in the transaction of land acquisition for the construction site of PemalangBatang Toll Road (PBTR), The field data were analyzed qualitatively and literature that only retrieve data related to the issues discussed. Legal uncertainty for public land needs to be a concern for the government. As for efforts to be made, among others, regulatory arrangement to produce quality legal regulations, Based on Presidential Decree Number 36 of 2005 and Presidential Decree No. 65 of 2006, there are two points that are important in the release of land property rights to state land. The process of transitional status of land property rights to state land to development projects PemalangBatang toll road has reached $99.21 \%$ starting in October 2017 . This indicates that the transition process is almost completed and the soil needs to be studied further whether the operation has been fulfilling the principle of justice, Based on Presidential Decree Number 36 Of 2005 and Presidential Decree No. 65 of 2006, there are two points that are important in the release of land property rights to state land. The process of transitional status of land property rights to state land to development projects Pemalang-Batang toll road has reached $99.21 \%$ starting in October 2017. This indicates that the transition process is almost completed and the soil needs to be studied further whether the operation has been fulfilling the principle of justice, Based on Presidential Decree Number 36 Of 2005 and Presidential Decree No. 65 of 2006, there are two points that are important in the release of land property rights to state land. The process of transitional status of land property rights to state land to development projects Pemalang-Batang toll road has reached $99.21 \%$ starting in October 2017. This indicates that the transition process is almost completed and the soil needs to be studied further whether the operation has been fulfilling the principle of justice.

Keywords: Switching Status of Land; Land Property; State Land.
\end{abstract}

\section{Introduction}

Land has a broad meaning, because in not only seen from the physical aspect, but also social, cultural, political, legal, manufacturing, defense, security and economic aspects. Therefore the land has economic aspects, the land ownership rights of merchantability or can be routed through a grant, sale and purchase, inheritance and others. On the implementation of the necessary land acquisition, the government has made the rule of law to underpin these activities. Although the regulation is already stated in the

\footnotetext{
${ }^{1}$ Students of Master Program (S2) in Notary, Faculty of Law, UNISSULA, Semarang Email: resdian2@yahoo.co.id

2 Lecturer of Faculty of Law UNISSULA
} 
provision of land should not be detrimental to the public interest and the interests of society. However, in reality there are many problematic protracted.

The number of construction and the limited availability of land year after year, an impact more difficult to acquire land in order to meet the needs of ${ }^{3}$, This has an impact on land prices skyrocketing out of control, and the development trend of the use of land in an irregular manner, especially in strategic areas.

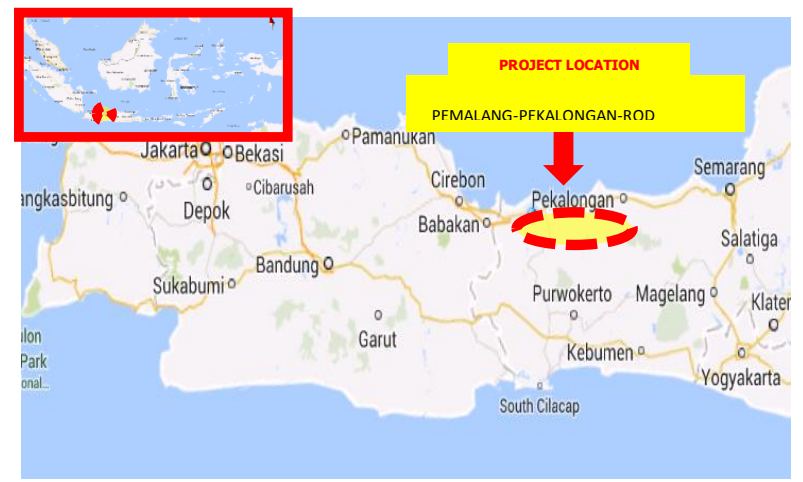

Figure 1. Construction of Pemalang-Batang Toll Road

The practice of transfer of rights over land usually involve communities affected by development projects such as those in Pemalang-Batang in development projects of toll Pemalang rod that crosses land property rights of citizens where through a waiver of land which was originally freehold to the ground purchased by the state for use as a means of public interest. Based on this background, the author describes the theory relating to the transitional status of Land Property Rights to the ground state and the transitional status of land property rights to state land on the construction of the Pemalang-Batang Toll Road (PBTR).

\section{Research Methods}

The method used in this research is juridical empirical method. Judicial approach in this study is intended that this study the terms of the science of Agrarian Law (literature) and the rules written as secondary data. This method is useful to know the rules in force, in particular the rules relating to the role of the Notary in the transaction of land acquisition for the construction site Pemalang-Batang Toll Road (PBTR).

This research is descriptive. Descriptive analysis is a method or procedure to solve the problem of research by describing the state of the object under study (people, public institutions, companies, agencies and others) as it is based on actual facts that exist at the present time. With analytical descriptive study, it can be analyzed and compiled the data collected, so that it can be concluded that a general nature, as well as giving a clear picture of the role of the Notary in the transaction of land acquisition for the construction site PBTR.

Sources of primary data obtained through interviews. interviews used in this study is not focused interviews to determine the condition and status of the transition process of land property rights to state land.

\footnotetext{
${ }^{3}$ Sidiq, M. E., Purnawan, A. 2018. Peran Notaris Dalam Transaksi Pengadaan Tanah Untuk Lokasi Pembangunan Komplek Perkantoran Pemerintah Kabupaten Sekadau. Jurnal Akta Vol 5 No. 1. March $1^{\text {st }}, 2018$
} 
Data Collection Method various legal materials, either in the form of legislation, codes of professional conduct, literartur, scientific work, the results of previous studies, documents, opinions of legal practitioners, magazines, and other relevant books relating to the responsibilities of transitional status of land property rights into state land.

The field data were analyzed qualitatively and literature that only retrieve data related to the issues discussed.

\section{Results And Discussion}

\subsection{The Theory Of Legal Certainty Transitional Status Of The Land}

Frequent problems in land registration, either dual ownership certificate, as well as poor land administration, causing the loss of the land ownership rights for the person concerned. This happens because of the weakness of the principles adopted in stelsel negative publicity in land registration, namely the principle of the opportunities of others to deny the validity of the name in the certificate of land rights. The principle of land registration can be referred to in article 19 (2) c BAL and Article 32 (1) PP No. 24 of 1997.

This means that the law only provides assurance to someone who has proof of ownership rights. Law is often deemed to be less protective of their owners. ${ }^{4}$ Legal uncertainty for public land needs to be a concern for the government. As for efforts to be made, among others, regulatory arrangement to produce quality legal regulation, implementation of the theory of views on the political will and the problem of Planning Political Will, legal supervision and grounded in views on national security. ${ }^{5}$

\subsection{Authorities Theory Transitional Status Of The Land}

The authority is seen as a right to run one or more management functions, including setting (regulation and standardization), maintenance (administration) and or a particular matter. ${ }^{6}$

The elements include the influence of authority, legal basis and legal conformity. Influence covers the use of authority is meant to control the behavior of legal subjects. The legal basis for demanding authority should be appointed legal basis. Conformity of law means that the authorities must have a standard that includes common standards (for all types of authority) and special standards (for certain types of authority).

The nature of the authority includes the authority is bound, facultative authority, and the authority is free. The authority are bound to occur when basic rules to determine when and under what circumstances the authority can be used. Facultative authority occurs when a state administrative agency is not required to impose its authority or lesser extent there are still options. Free authority occurs when regulations give freedom to the state administrative bodies to determine the contents of the decision taken.

PPAT has authority as the right to perform its functions in terms of a deed and registration of land in Rule The head of the National Land Affairs of the Republic of

\footnotetext{
${ }^{4}$ Damayanti, P. 2015. Tinjauan Yuridis Peranan Pejabat Pembuat Akta Tanah dalam Pendaftaran Peralihan Hak Atas Tanah (Studi di Kantor PPAT Kabupaten Gunung Kidul). UIN Sunan Kalijaga, Yogyakarta Indonesia

${ }^{5}$ A. P. Perlindungan, Permohonan Kepastian Hukum atas Hak atas Tanah menurut Peraturan yang berkaitan, Proceedings of the Seminar USU Faculty of Law 199 dated 19 October, p 2

${ }^{6}$ Philipus M. Hadjon, tentang wewenang, Yuridika, No. 5 \& 6, 1997, p. 100
} 
Indonesia Number 1 Of 2006 on Provisions Implementation of Government Regulation No. 37 of 1998 Article 1 paragraph 1 of the Regulations Title Deed Official Land stated that PPAT is a public official who is authorized to make the deeds of authentic regarding certain legal actions and over land rights or ownership of the apartment units. $^{7}$

\subsection{Soil Release Into The State Land Property Rights}

Article 27 of Act No. 5 of 1960 on Agrarian mention that the factors that cause the abolishment of the land ownership and land fell to the countries which are due to the revocation of rights under Article 18 of Act No. 5 of 1960 on Principles Agricultural, released voluntarily by the owner, revoked in the public interest, the land is abandoned, because the subject of rights do not qualify as subjects of property rights to land, because of transfer of rights that resulted in the land is transferred to another party who does not qualify as a subject of property rights on land, the land destroyed, for example natural disasters

The second reason is the terms of the owner or the giver. But this problem can also be viewed from the people who earn or receive. By doing a certain legal actions, such as the sale and purchase, exchange, donation and so on. in which case ownership occurs when the owner (originally) are still alive. The legal act could also be the owner at the time was still alive but came about after he died, namely the so-called grant will or legaat.

In western law, transfer of rights occurs when the owner died and it's inherited wealth either in the form of assets or liabilities. Whereas in customary law, they are not so because after the owner died, still to be resolved is completed and the remaining receivable debt fell on his heir. If there is no remainder, nothing is inherited. So in the customary laws inherited it only assets alone.

Land rights switchover can occur due to inheritance without a will and the deed of transfer. According to the Civil Code if the holder of rights over the land died, those rights law have been transferred to his heir. The transfer of rights to the heirs, namely anyone who included the heirs, what fraction of each and how unshared. Governed by the laws of inheritance of the deceased holder of the rights concerned and not by the law of the land. Land laws provide provisions on land ownership that comes from inheritance and matters regarding the provision of a letter of proof of ownership by heirs.

In contrast to the ownership of the land for inheritance without a will that happen because of the law with the death of the holder of the rights, the legal act of transfer of rights, land rights are concerned accidentally transferred to other parties, forms of displacement can be purchase, exchange, grant, awarding according to custom, the inclusion in the company or "inbreng" and grant probate or "legaat"8

The legal acts, performed at the time of the right holder is alive and is a legal act of transfer is in cash, unless the grant will. This means that by doing a legal act, the right over the land is transferred to another party. Sale and purchase, exchange, donation, according to customs and revenue administration in the company, as well as the implementation of the grant will, conducted by the parties before the Land Deed Officer.

\footnotetext{
${ }^{7}$ Ibid, p 101

8 Boedi Harsano, Indonesian Agrarian Law, History Formation of the Basic Agrarian Law, Content and Implementation, Jakarta: Djambatan, 2003, p. 332
} 
Land has a social function and utilization should be able to improve the welfare of the people. It needs to be developed for spatial planning and land use nationwide so that the utilization of the land can be coordinated between the various types of use while maintaining the conservation of nature and the environment and preventing the use of land which contravenes the public interest and the interests of development.

According to Article 1 (6) of Presidential Regulation No. 36 Of 2005 is the release of rights over land is releasing activity legal relationship between the holders of land rights to the land under their control to provide compensation on the basis of consensus. The term "waiver of land" are not mentioned in Government Regulation No. 6 of 2006 on State Property Management Region but uses the term "alienation" is a transfer of ownership of state property area as follow-up and removal by way of sale, exchanged, donated or supplied as government capital. (Article 1 paragraph 15 in conjunction with Article 45). Transference of state property or the area in the form of land and buildings (Article 46 paragraph (1)).

Definition of land acquisition by Indonesian Presidential Regulation No. 36 of 2005 expanded and Presidential Decree No. 55 of 1993 mentioned in Article I point 3 is any activity to obtain land by giving compensation to the release or transfer their land, buildings, plants, and objects relating to the land or the land revocation.

When viewed and the provisions of Presidential Regulation No. 36 Of 2005 and Presidential Decree No. 65 of 2006, there are two points that are important in the release of land property rights to state land. First, the concept of the release or surrender and revocation of land rights are several ways to obtain land for implementation of development for public interest. Second, regarding the compensation given to those who suffered losses as a result and the land acquisition.

As for the transfer of land property rights to state land in Pemalang-Batang toll road development outlined in Table 1.

Table 1. Soil Transition Process

\begin{tabular}{|l|c|c|c|}
\hline \multicolumn{1}{|c|}{ Period } & Free land & Land Not Free & $\begin{array}{c}\text { Total Land } \\
\text { Requirement }\end{array}$ \\
\cline { 2 - 4 } & $\mathbf{\%}$ & $\mathbf{\%}$ & $\mathbf{\%}$ \\
\hline Friday, August 26, 2016 & $13.80 \%$ & $86.20 \%$ & $100.00 \%$ \\
\hline Friday, September 2, 2016 & $16: 16 \%$ & $83.84 \%$ & $100.00 \%$ \\
\hline Tuesday, September 20, 2016 & $25.14 \%$ & $74.86 \%$ & $100.00 \%$ \\
\hline $\begin{array}{l}\text { Wednesday, September 28, } \\
\text { 2016 }\end{array}$ & $32.49 \%$ & $67.51 \%$ & $100.00 \%$ \\
\hline Friday, October 14, 2016 & $37.36 \%$ & $62.64 \%$ & $100.00 \%$ \\
\hline Friday, November 4, 2016 & $37.42 \%$ & $62.58 \%$ & $100.00 \%$ \\
\hline Friday, November 11, 2016 & $54.35 \%$ & $45.65 \%$ & $100.00 \%$ \\
\hline Friday, November 25, 2016 & $62.25 \%$ & $37.75 \%$ & $100.00 \%$ \\
\hline Friday, January 27, 2017 & $86.99 \%$ & $13.01 \%$ & $100.00 \%$ \\
\hline Friday, February 17, 2017 & $93.62 \%$ & $6.38 \%$ & $100.00 \%$ \\
\hline Friday, August 4, 2017 & $99.09 \%$ & $0.91 \%$ & $100.00 \%$ \\
\hline Friday, October 13, 2017 & $99.21 \%$ & $0.79 \%$ & $100.00 \%$ \\
\hline Source: Waskita, 2018 & & & \\
\hline
\end{tabular}

Source: Waskita, 2018

The process of transitional status of land property rights to state land has reached $99.21 \%$ starting in October 2017 . This indicates that the transition process is almost 
completed and the soil needs to be studied further whether the operation has been fulfilling the principle of justice. Based on these data researchers need to explore in future studies whether during the transition status of the land is already using the principles of justice. In addition, the expected constraints that happen to look for solutions that meet the principles of justice.

\section{Closing}

\subsection{Conclusions}

- Legal uncertainty for public land needs to be a concern for the government. As for efforts to be made, among others, regulatory arrangement to produce quality legal regulation.

- Based on Presidential Decree Number 36 Of 2005 and Presidential Decree No. 65 of 2006, there are two points that are important in the release of land property rights to state land. First, the concept of the release or surrender and revocation of land rights are several ways to obtain land for implementation of development for public interest. Second, regarding the compensation given to those who suffered losses due and land acquisition.

\subsection{Suggestion}

The process of transitional status of land property rights to state land to development projects Pemalang-Batang toll road has reached $99.21 \%$ starting in October 2017 . This indicates that the transition process is almost completed and the soil needs to be studied further whether the operation has been fulfilling the principle of justice,

\section{References}

[1] Damayanti P. 2015. Tinjauan Yuridis Peranan Pejabat Pembuat Akta Tanah dalam Pendaftaran Peralihan Hak Atas Tanah (Studi di Kantor PPAT Kabupaten Gunung Kidul). UIN Sunan Kalijaga Yogyakarta, Indonesia

[2] A.P. Perlindungan Permohonan Kepastian Hukum atas Hak atas Tanah menurut Peraturan yang berkaitan Prosiding Seminar Fakultas Hukum USU on 19 oktober 199.

[3] Harsono, Boedi. 2003. Menuju Penye murnaan Hukum Tanah Nasional, dalam Hubungannya dengan TAP MPR Nomor IX/MPR/2001. Penerbit Universitas Trisakti, Jakarta

[4] Philipus M. Hadjon. Tentang Wewenang, Yuridika, No. 5 \& 6 Tahun 1997

[5] Sidiq, M. E., Purnawan, A. 2018. Peran Notaris Dalam Transaksi Pengadaan Tanah Untuk Lokasi Pembangunan Komplek Perkantoran Pemerintah Kabupaten Sekadau. Jurnal Akta Vol 5 No. 1 Maret 2018 